\title{
The Letter Hamzah: Highlights of Origin and Background
}

Felza Zulhibri bin Abd Hamid, Nor Hafizi Yusof, Muhamad Fadlly bin Ismail \& Rozaimi bin Abu Samah

To Link this Article: http://dx.doi.org/10.6007/IJARBSS/v11-i11/11555

DOI:10.6007/IJARBSS/v11-i11/11555

Received: 09 September 2021, Revised: 11 October 2021, Accepted: 23 October 2021

Published Online: 07 November 2021

In-Text Citation: (Hamid et al., 2021)

To Cite this Article: Hamid, F. Z. bin A., Yusof, N. H., Ismail, M. F. bin, \& Samah, R. bin A. (2021). The Letter Hamzah: Highlights of Origin and Background. International Journal of Academic Research in Business and Social Sciences, 11(11), $561-568$.

Copyright: (c) 2021 The Author(s)

Published by Human Resource Management Academic Research Society (www.hrmars.com)

This article is published under the Creative Commons Attribution (CC BY 4.0) license. Anyone may reproduce, distribute, translate and create derivative works of this article (for both commercial and non-commercial purposes), subject to full attribution to the original publication and authors. The full terms of this license may be seen at: http://creativecommons.org/licences/by/4.0/legalcode

Vol. 11, No. 11, 2021, Pg. $561-568$

Full Terms \& Conditions of access and use can be found at http://hrmars.com/index.php/pages/detail/publication-ethics 


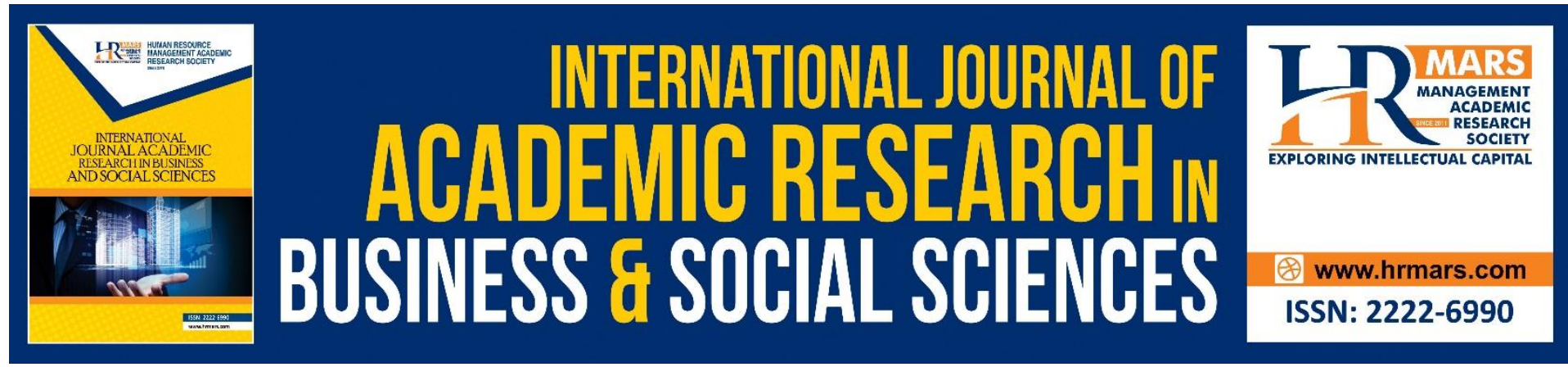

\title{
The Letter Hamzah: Highlights of Origin and Background
}

\section{Felza Zulhibri bin Abd Hamid', Nor Hafizi Yusof², Muhamad Fadlly bin Ismail ${ }^{3} \&$ Rozaimi bin Abu Samah ${ }^{4}$ \\ ${ }^{1}$ International Islamic University Malaysia (IIUM), ${ }^{2}$ Universiti Sultan Zainal Abidin (UniSZA), \\ ${ }^{3}$ Kolej Universiti Islam Pahang Sultan Ahmad Shah (KUIPSAS), ${ }^{4}$ Universiti Malaysia Pahang}

(UMP)

Email: felza@iium.edu.my, nhafizi@unisza.edu.my, fadlly@kuipsas.edu.my, rozaimi@ump.edu.my

\begin{abstract}
Hamzah is a difficult letter in pronunciation compared to other letters because its point of articulation (makhraj) is located at the bottom part of the throat, the farthest compared to other points. Therefore, the symbol of hamzah also has a diverse background based on the hamzah letter identity, which has a concession (rukhsah) in the expression due to the difficulty of pronouncing it. The problem has caused confusion among the community to understand the scope of hamzah symbols found in the mushaf because the Muslim community, especially in Malaysia, is bound by the narration of Hafs bin Sulayman al-Kufi that does not reveal the change of the letter hamzah based on its identity. Therefore, the purpose of this study was to reveal the correct understanding of the scope of hamzah letters involving symbols, colours and vowel marks (lines or harakat) based on the history recorded by qurra'. This descriptive study discusses the views of qurra' related to the letter hamzah, specifically involving symbols, colours and vowel marks (lines or harakat). All data were analysed using inductive and conductive methods. The findings show that the letter hamzah has a diverse background referring to its symbols, colours and vowel marks (lines or harakat). All these backgrounds cannot be realised within the community when they are still bound by the narration of Hafs bin Sulayman al-Kufi. If this understanding is not explained in detail to the public, it is worried that the community will be confused about the identity of the letter hamzah that is subject to various changes in all aspects, whether involving symbols in the mushaf or the variety of pronunciation based on ahruf al-Sab'ah. This study can also be an added value for teachers of the Quran in understanding the scope of the letter hamzah as one of the letters in the hija'iyyah letters.
\end{abstract}

Keywords: Hamzah, Symbol, Hija'iyyah, Hafs

\section{Introduction}

The Muslim community in Malaysia has been reciting the Quran for many years with the narration of Hafs bin Sulayman al-Kufi. This phenomenon has already created a confusion on the understanding about the origin and background of the symbol of the letter hamzah. It is 
quite difficult to clear the confusion because the majority community in Malaysia has no information about the knowledge of al-Qira'at (Jusoh, 2001: xvi). The confusion needs to be clarified from the beginning of the creation of the symbol until the relationship of pronunciation changes based on the position of the letter hamzah in a word. The confusion is increasingly difficult to overcome because the method of reciting the Quran based on the narration of Hafs bin Sulayman al-Kufi has the least involvement in changing the pronunciation of the letter hamzah as al-Tahqiq except in three places based on the three

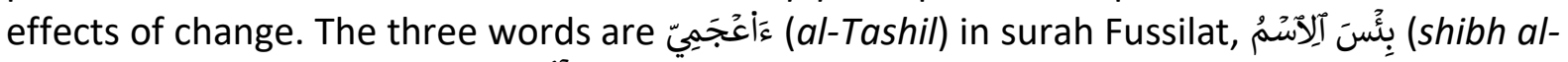
Naql) in surah al-Hujurat and آنتُتُوني (al-lbdal when restarting) in surah al-Ahqaf.

\section{Research Problem}

This study was conducted based on the confusion of facts about the letter hamzah from the time the symbol was created to the practical form of the symbol in the mushaf from one era to another. The letter hamzah is the only letter with diversities from all angles, including the background, symbol, and pronunciation.

The symbol of the letter hamzah in the mushaf is not based on the teaching of the Prophet s.a.w nor from the Sahabah r.a. The mushaf in the time of Rasullullah s.a.w and the Sahabah r.a did not have any harakat diacritics, i'jam diacritics or letter of hamzah. The creation of the symbol of the letter hamzah appeared in the time of al-Khalil bin Ahmad al-Farahidi al-Basri (Damrah, 2008: 24).

Therefore, this study is carried out to further clarify the facts involving the letter hamzah which refers to the origin and background of the letter in the situation where most Muslims in the world, especially in Malaysia, recite the Quran using the narration of Hafs bin Sulayman al-Kufi. This narration lacks much impact in providing a complete understanding of the scope of the letter hamzah.

\section{Research Objectives}

This study was conducted to achieve the following objectives:

1. Explain the identity of the letter hamzah, which is precisely based on the history of writing the mushaf.

2. Study the origin and background of the symbols, colours and harakat diacritics of the letter hamzah.

3. Study the practicality of the symbol of the letter hamzah in the mushaf.

\section{Origin and Background of the Letter Hamzah}

The letter hamzah is called as al-Halq (Al-Ansari, 1998: 42). It is also known as al-Alif alMutaharrikah with the characteristics of jahr, shiddah, istifal, infitah and ismat (Safaqisi, 1974: 47). The study will explain the diversity of the letter hamzah in terms of background, referring to the origin of the creation of symbols up to the practicality applied in the mushaf today. The discussion on the letter hamzah from the background perspective is divided into five parts (Muhaysin, 1995: 27-31), namely symbols, colours, harakat diacritics, conditions and situations. This study covers the issue of symbols, colours and harakat of hamzah letter only. 


\section{The Symbols of the Letter Hamzah}

After the generation of Salafiyyun, the qurra' introduced the symbol of the letter hamzah based on two opinions (al-Tunisi, 1995: 231). First, the letter hamzah is given a black round symbol (.). This symbol resembles a dot in a letter, whether the letter hamzah is muhaqqaqah or musahhalah. This opinion is held by the authors of the mushaf. Second, the letter hamzah is given a small 'ayn letter $(\varepsilon)$. This opinion was held by grammarians and writers of letters and poems during the early days of Islam, as mentioned by al-Kharaz (al-Tunisi, 1995: 231):

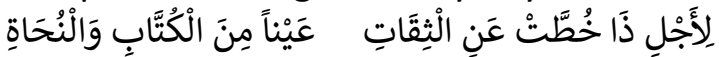

Meaning: "For this reason (reasonably discussed earlier), written the symbol of the letter hamzah with a small 'ayn letter by the letter writers and poets and the grammarians".

Al-Dani stated that this situation occurred for two reasons (al-Tunisi, 1995: 231). First, the letter hamzah has the characteristic of shiddah and the letter 'ayn has the characteristic close to shiddah, and this situation does not apply to other halq letters. Second, both letters ('ayn and hamzah) are halq letters, and this situation does not apply to other shiddah letters al-Kharaz said (al-Tunisi, 1995: 231):

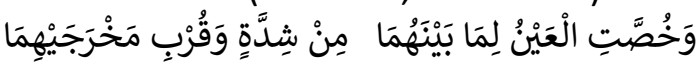

Meaning: "Specialized the writing of the letter hamzah to the small letter 'ayn on a reasonable basis between the letter 'ayn and the letter hamzah referring to the shiddah characteristic and the close makhraj of both letters"

\section{The Colours of the Letter Hamzah}

When it comes to colour issues, it is based on six types of hamzah letter (Muhaysin, 1995: 27):

1) Muhaqqaqah: The letter hamzah that does not change in terms of pronunciation, for example:

أُنْلَ

Surah al-Baqarah, 2: 4

The letter hamzah is marked with a yellow round dot symbol, as mentioned by al-Kharaz (Al-Tunisi, 1995: 225):

فَضَبْطُ مَا حُقِقِقَ بِالصَّفْراءِ نَقْطُ

Meaning: "Coloured the letter hamzah muhaqqaqah in yellow..."

This yellow colouring covers all the letters of hamzah that have no change in terms of original pronunciation. Such hamzah letters can be categorised as follows:

i) Located at the beginning of a word:<smiles>[AlH2]</smiles>

Surah al-Baqarah, 2: 33

ii) Located in the middle of a word: سَأَلُوْاً

Surah al-Nisa', 4: 153

iii) Located at the end of a word: بَََاً

Surah al-'Ankabut, 29: 20

iv) At the letter alif, as in the previous examples.

v) At the letter $y a^{\prime}$ :<smiles>[AsH2]</smiles> 
Surah al-Inshiqaq, 84: 21

vi) At the letter waw: يَعْبَؤْاْ

Surah al-Furqan, 25: 77

vii) Places like the previous examples.

viii) No specific location (by itself):

مِّلْن

Surah Ali 'Imran, 3: 91

ix) With harakat, as in the previous examples.

x) Sukun (no harakat): جִنْتُمْ

Surah Maryam, 19: 89

xi) Isolated, no other hamzah in the word, as in the previous examples.

xii) Combined with another hamzah: أَوَنْبِيُكُكُم

Surah Ali 'Imran, 3: 15

2) Musahhalah

The letter hamzah is pronounced between the letter alif and fathah based on the recitation of al-Tashil, which only involves certain imams. Examples of words involved are as follows and only involve the second hamzah:

أَزَءَيْتَ

Surah al-Ma'un, 107: 1

The letter hamzah is marked with a yellow round dot symbol, as mentioned by al-Kharaz (al-Tunisi, 1995: 225):

وَمَا سُهِّلَ بِالْخَمْرَاء

Meaning: "And the musahhalah hamzah is coloured red"

3) Mubdalah harfan muharrakan

The letter hamzah is changed to letter with harakat based on the recitation of al-lbdal, which only involves certain imams, for example:

i) The letter hamzah is changed to the letter $y a^{\prime}$ :

لِيَلَّلا: لِيَّلَّا

Surah al-Baqarah, 2: 150

ii) The letter hamzah is changed to the letter waw: مُؤَجَّلا: مُوَجَّلا

Surah Ali 'Imran, 3: 145

This letter hamzah is also marked with a red round dot symbol. This is because this issue falls into the category musahhalah, referring to the meaning of al-Tashil generally as li al-Takhfif, namely to ease the pronunciation of the letter hamzah as explained by al-Kharaz (al-Tunisi, 1995: 225):

وَذَا الذِي ذَكَرْتُ فِي الْمُسَهَّلِ سُهِّلَ بَيْنَ بَيْنَ أَوْهِ بِالْبَدَلِ

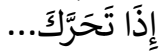

Meaning: "And what I have mentioned in the category of al-Musahhil, (coloured red) is only to al-Tashil bayna bayna and al-Ibdal if the letters recited by al-Ibdal have harakat (not al-Ibdal of the letter with sukun either the letter mad or sukun sahih)..." 
With the details stated by al-Kharaz, it is understandable even though many categories of hamzah letters are basically included in the term musahhalah, only the categories al-Tashil bayna bayna and mubdalah harfan muharrakan are coloured red when involving the method of colouring the hamzah letter symbols.

4) Mubdalah harf mad

The letter hamzah is changed to letter with harakat based on the recitation of al-lbdal, which only involves certain imams:

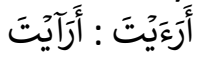

Surah al-Ma'un, 107: 1

There is no colour for the issue of hamzah like this because the letter hamzah has changed into other letters (al-Öabba', 1995: 28).

5) Manqulah

The harakat of the letter hamzah is removed based on the recitation al-Naql and only involves certain imams:

قَدْ أَفْلَحَ : قَدَ افْلَحَ

Surah al-Mu'minun, 23: 1

Such hamzah letters cannot be coloured because the harakat for letter hamzah is removed to another letter, as mentioned by al-Shatibi (Shatibi, 1996: 19):

وَاحْذِفْهُ مُسنهِها

Meaning: "And the letter hamzah is removed to ease the recitation"

6) Mahzufah

The letter hamzah is omitted in the recitation of al-Isqat and only involves certain imams. This issue only involves the first hamzah:

جَآءَ أَمَرُنَا : جَآَ أَمْرُنَا

Surah al-Mu'minun, 23: 27

Such hamzah letters cannot be coloured. Because the letter hamzah no longer exists.

However, the current practice is not like the above discussion due to some difficulties. If the letter hamzah is in the categories of musahhalah or mubdalah harfan muharrakan, it is given a black round symbol. No symbol is given for the letter hamzah in the category of mubdalah harf mad, manqulah and mahzufah (al-Dabba', 1999: 110).

\section{The Harakat of the Letter Hamzah}

The majority of the dabt scholars agreed to put some rulings involving the harakat of the letter hamzah as follows (Muhaysin,1995: 28):

1) Muhaqqaqah: The majority of the dabt scholars agreed to put a harakat to the letter hamzah.

2) Musahhalah: The majority of the dabt scholars agreed not to put a harakat to the letter hamzah.

3) Mahzufah: The majority of the dabt scholars agreed to omit the letter hamzah and its harakat.

4) Manqulah: The majority of the dabt scholars agreed to remove the harakat of the letter hamzah to the sukun sahih letter before it there is a sukun sahih letter after it: قَذَّ أَفْلَحَ : قَدَ افُلَحَ

Surah al-Mu'minun, 23: 1

If there is a tanwin after the letter hamzah, the majority of the dabt scholars agreed to remove the harakat of the letter hamzah verbally without changing the writing: عَذَابُ أَلَيم : عَذَابُنَ لِيم 
Surah al-Baqarah, 2: 104

5) Mubdalah harfan muharrakan: Involves al-Ibdal of the letter $y a^{\prime}$ : لِيَلَّا: لِيَلَّا

Surah al-Baqarah, 2: 150

This issue is divided into two opinions:

i) The letter $y a^{\prime}$ replacing the letter hamzah without harakat.

ii) The letter $y a^{\prime}$ replacing the letter hamzah with harakat.

The second opinion has been practised as in the previous examples.

6) Mubdalah harf mad: The majority of the dabt scholars agreed to put a harakat to the letter hamzah that is recited using al-lbdal (second hamzah) and is divided into two types:

i) Single hamzah.

The letter hamzah and its harakat are omitted and replaced with a mad symbol at that particular location:

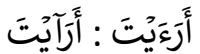

Surah al-Ma'un, 107: 1

ii) Combined with another hamzah: This issue is divided into five parts:

a) Combination of two hamzah letters.

Involves hamzah istifham with hamzah was/ in one word: أالذَّكَرَيْنِ : عَآلََّّكَرَيْنِ

Surah al-An'am, 6: 143

Hamzah wasl and its harakat are omitted and replaced with a mad symbol at that particular location:

b) Combination of the hamzah letters.

In the case where the second hamzah is not hamzah was/ and after that, there is a sukun sahih letter:

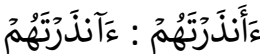

Surah al-Baqarah, 2: 6

The second hamzah and its harakat are omitted and replaced with a mad symbol at that particular location: Some opinions say there is no need to put any symbols, but the opinions that say there should be a mad symbol are practised.

c) Combination of the hamzah letters.

Refers to hamzah istifham with hamzah wasl in one word, and after that, there is harakah' aridah (incoming harakat). This category also involves the recitation of al-Naql:

أالآنَ : عآَآكَنَنَ

Surah Yunus, 10: 51

The second hamzah is omitted, and a mad symbol is not placed at that particular location unless it involves prolonging a mad, as in the previous examples. Some opinions say a mad symbol should be placed and others say it is not, and the opinions that say there should be a mad symbol are practised.

d) The letter hamzah combined with another letter:

Both letters are in a word, and after that, there is harakah asliyyah (original harakat):

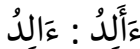

Surah Hud, 11: 72 
The second hamzah and its harakat are omitted and no mad symbol is placed at that particular location:

e) The letter hamzah combined with another hamzah in two words:

The second hamzah and its harakat are omitted, and no mad symbol is placed at that particular location:

شَآَاء أَنَشَرَهُ : شَآَء انشَرَهُ

Surah 'Abasa, 80: 22

To further strengthen the the previous explanations, the study concludes with the words of al-Kharaz (al-Tunisi, 1995: 238-239):

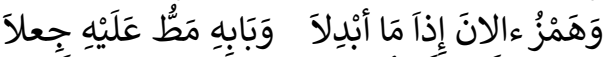

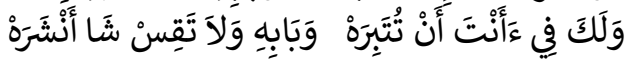

Meaning: "And the second hamzah in الانَ and similar examples (involving hamzah istifham combined with hamzah wasl), a mad symbol is placed. And the same goes for other examples

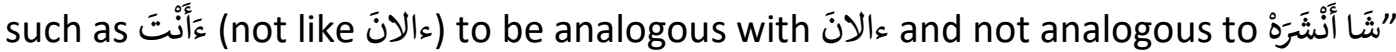

\section{Conclusion}

Based on the findings, the authors have presented the background of the letter hamzah involving symbols, colours and harakat based on the facts recorded by scholars. This study has also unravelled some issues involving the letter hamzah that is often changed in terms of shape, colour and harakat based on the identity of the letter hamzah. However, all the findings will not be appreciated if the community is still bound to the narration of Hafs bin Sulayman al-Kufi.

\section{References}

Al-Qasih, A. B. A. U. M. (t.t). Sharh Talhis al-Fawa'id wa Taqrib al-Mutaba'id. Cairo: Maktabah al-'Azhariyyah li al-Turath.

Al-Dani, A. A. U. S. (1978). Al-Muqni' fi Rasm Masahif al-'Amsar ma'a Kitab al-Naqt. (tahqiq: Muhammad al-Sadiq Qamhawi). Cairo: Maktabah al-Kulliyyat al-'Azhariyyah.

Al-Imam, A. A. (1998). Variant Readings of The Qur'an: A Critical Study of Their Historical and Linguistic Origins. Virginia: International Institute of Thought Herndon.

Al-Dabba, A. M. (1999). Samir al-Talibin fi Rasm wa Dabt al-Kitab al-Mubin. Cairo: Maktabah al-Azhariyyah li al-Turath, 20.

Yusuf, J. M. M. M. A. (1994). Tayyibah al-Nashr, (tahqiq: Muhammad Tamim al-Zu'bi).

Al-Syathibi, Q. F. A. R. (1996). Hirz al-Amani wa Wajh al-Tahani. (tahqiq: Muhammad Tamim al-Zu'bi).

Hassan, S. A., \& Khairuldin, W. M. K. F. W. (2020). Research Design Based on Fatwa Making Process: An Exploratory Study. International Journal of Higher Education, 9(6), 241-246.

Said, N. A., \& Khairuldin. (2017). Freedom of Speech in Islam and its Connection with Street Demonstrations. International Journal of Academic Research in Business and Social Sciences, 7(4), 122-129.

Muhaysin, M. S. (1995). Irshad al-Talibin ila Dabt al-Kitab al-Mubin. Cairo: al-Idarah alMa'ahid al-Azhariyah.

Al-Tunisi, I. A. S. M. (1995). Dalil al-Hairan 'ala Mawrid al-Zam'an fi Fannay al-Rasm wa alDabt. Beirut: Dar al-Kutub al-'Ilmiyyah.

Jusoh, M. R. (2008). Tarikh al-Qur'an \& rasm Uthmani. Kuala Lumpur: Pustaka Khodim alMushaf. 97. 